\title{
CONFRONTATION WITH REALITY IN CATULLUS 51
}

\author{
Sjarlene Thom, Department of Latin, University of Stellenbosch
}

It is hardly possible to focus on Catullus 51, without keeping Sappho fr. 31 also in mind. Not only because the one poem can be read as a translation (of sorts) of the other, but also since both poems describe a confrontation with reality where a situation of psychosomatic suffering threatens to overwhelm the individual.1 Both poems reflect the magnificent rally of mental and poetic capacity to combat this possibility.

It is quite obvious that Catullus knew the Sappho poem. In fact in his own poem he followed the Sappho poem so closely that Wilamowitz spoke of an "Übersetzungsübung" and a critic of the standing of Copley (1974:36) has criticised the Sappho poem for not being as succinct as the so-called "translation"! Irrespective of their differences the Greek and Roman world left us an amazing legacy of the restorative power of creative intelligence in these two poems.

For the purpose of this paper I do not propose to compare the two poems.2 In my analysis I will focus mainly on the confrontation with reality as expressed in the Catullus poem. From time to time I will also refer to the obvious parallel in situation of the Sappho poem. ${ }^{3}$

The structure of the Catullan poem seems to suggest a strong comparison between a sudden heightened experience of reality as described in the poem and the onslaught of an illness:

1-5a: The normal situation (reality)/absence of pathology

5b-12: IIlness:

5b-9b: onset of illness

9b-12: turn for the worse

13-16: Diagnosis and prognosis

The poem seems to equate a poetic experience and a physical experience as follows: What holds true for the physical experience of reality in, for instance, the presence of illness holds true for the poetic experience in the presence of the beloved.

In the Catullus poem a concrete and solid ille is repeated twice at the beginning of the first

1 That Catullus' reaction was considered an illness has traditionally been accepted; cf. Snell 1931:93.

2 See Schnelle 1933, who gives a good line by line analysis of both poems, but draws no conclusions from this comparison. As recently as 1988 Lefevre (1988:324) added this wry comment on Sappho-Catullus comparisons: "Aber zum Verständnis des Catull-Gedichts konnte die Ode [Sappho f. 31] so gut wie nichts beitragen".

3 For a thorough analysis as well as a bibliography of the Sappho poem, see Thom 1990. 
two lines and is referred to again in qui (v. 3). This seems to emphasise solid general reality in Catullus as opposed to detailed and specific sense impression in Sappho.4 Striving after an even more realistic assessment of the ille, the Catullan observer reformulates the original ille...par esse deo videtur (v. 1). He now proposes the superlative ille...superare divos [mihi videtur] (v. 2). An impression becomes more real but at the same time more tractable when reduced to its proper proportions by the power of language. Interestingly enough in this case the power of language opts for increasing rather than decreasing the proper proportions of the situation in which the ille finds himself when his position is reformulated in v. 2.5.5 Psychologically speaking the reformulation makes sound sense, since a more precise description of the impression created by the ille, resembles reality more clearly. Even the super-natural world of the gods is acknowledged in terms of a normal accepted reality. ${ }^{6}$

The poet-persona who reformulates a first impression of the other man, now motivates this intellectual effort to cope with reality. The other man's body language (sedens adversus identidem te spectat et audit, vv. 3-4) suggests that he is comfortable and at ease with his surroundings. Ostensibly he can cope with the reality of Lesbia's presence. Apparently he can countenance and enjoy her presence and her laughter without obvious physical stress. $\mathrm{He}$ is after all described as par deo (v. 1). Ironically the three verb forms sedens, spectat and audit used to characterise the man, also describe the observing poet-persona if only by implication. The observer experiences the same general reality as the ille. He also hears and sees the girl, as is clear in dulce ridentem (v. 5) and te...aspexi (vv. 6-7) but with completely different results. 7 Hearing Lesbia's laughter causes the poet to describe himself as misero quod omnis eripit sensus mihi (vv. 5-6). Now it is clear why the poet described the ille (vv. 1-2) as par deo and even as superare divos (vv. 1-2). The poet-persona in direct contrast to the ille, is misero - a word which does not occur in the Sappho poem. If hearing Lesbia caused the poet-persona to describe himself as misero, the reality of seeing her (nam simul te, Lesbia, aspexi, vv. 6-7) causes a psycho-somatic response which threatens his whole being.

The remainder of the poem concentrates on the poet-persona's physical response (vv. 5-12) as well as mental reaction (vv. 13-16) to the reality of the situation reflected in the first five lines. The focus in the Catullan poem is on the poet-persona's reaction to a situation which the other man has so obviously taken in his stride. The poet-observer needs only glance at Lesbia (simul te, Lesbia, aspexi, ww , 6-7 as opposed to the identidem te spectat, vv. 3-4 of the other man) when reality in the form of sense impressions starts overwhelming him. The ille's normal reaction described in such detail at the beginning of

4 The first two words of the two poems immediately indicate their different perspectives.

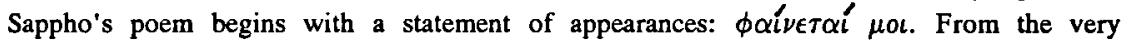
beginning it is obvious that the poetic experience reflected in this poem (fr. 31) will be filtered organically, as it were, through the first person observer. It is the poet's brilliant selection of specific details which characterises the Sappho poem.

5 See Fredricksmeyer 1965:159: "Verse two...constitutes an emphatic reassertion of the poet's appraisal of the state of ille as sublime and gives this assertion, moreover, the aspect of being carefully considered by him" (my emphasis).

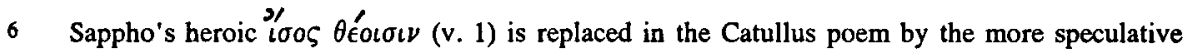
and at the same time more realistic and down to earth si fas est (v.2).

7 It seems to make most sense to take quod to refer to the immediately preceding dulce ridentem (v. 5) and nam to refer to te...aspexi (vv. 6-7). In this reading the poet's response to seeing and hearing Lesbia is in direct contrast to the ille's response to her. See Woodman 1978:78 for a clear account of the logic of these lines. 
the poem, forms a stark contrast to the susceptibility and even debility of the poet-persona. Instead of the quiet tete-à-tête between the man and the woman described in the first five lines, the poet-persona is depicted in total isolation, in a state of emotional upheaval cutting him off from all contact with his fellows (lingua...torpet... sonitu suopte tintinant aures and gemina teguntur lumina nocte, vv. 9-12.). All sight and sound is blocked out, all senses are cut off, all sense of communication is lost. According to Finamore (1984:14) "the symptoms he [Catullus] lists indicate an intense psychological state of anxiety." The poet is engulfed by this situation as comprehensively as an ill person is overwhelmed by disease. 8

The poet-persona has become the object of his own poem, or perhaps more precisely, the poet-persona experiencing tremendous emotional stress to the point of not being able to express himself as in lingua sed torpet (v. 9), hear or see anything (vv. 10-12) and to be aware only of inner turmoil tenuis sub artus flamma demanat (vv. 9-10), has become the object of his own poem.

What reality is it that confronts the poet-persona with such devastating results? The reaction to this reality, the symptoms described in the poem, are caused by perception and are experienced fleetingly though not superficially. Since this reaction is directly dependent on an impression gained via the physical senses (sight, hearing) it is quite possible that the reaction could subside, when this impression is blocked. This does not mean, however, that the impression which affects the poet-persona is imaginary. 9

Catullus uses the very graphic description of helplessly succumbing to illness to translate his experience of the overwhelming impact made on him by Lesbia's physical presence. The ille's normal reaction remains the foil of reality against which the poet-persona's abnormal reactions are to be considered. The poem embodies and as it were substantiates the reality of the experience. Describing the poet's sense experience of reality as an illness operates as a metaphor which conveys the degree of psychological helplessness experienced by the poet-persona. Of course the poet's aim is not to describe a physical illness. This illness is the result of a sense impression. The seriousness of the illness or of this reaction, only reflects the powerful impact of the original sense impression. The poet-persona's reaction is at the same time a measure of the irresistible power of the reality of Lesbia's influence.

Catullus himself, as the poet-persona, indicates how this illness should be interpreted by choosing to "translate" the well-known Sappho poem. He is not really translating Sappho f. 31 , but the situation depicted by her poem. His experience is something real with which he has to cope, just as the Sappho-persona had to come to grips with the effects of the sense impressions reflected in her poem.

The situation in the Sappho poem is much debated.10 It seems to be clearer in the Catullus poem. Analysis of this poem shows that a physical sense impression, sight (simul te, Lesbia, aspexi, vv. 6-7) causes a violent physical reaction in the observer. Subsequently physical symptoms are used to convey the impact of an emotional experience (vv. 9-12). The main point of comparison between the Sappho and the Catullus poems is that an

8 The interesting point is of course that the woman apparently has no such adverse affect on the ille. She is not a germ indiscriminately affecting any physical organism. This illness comes to him who is susceptible.

9 Practically all critics agree on the primary destructiveness of the impression. See for instance Itzkowitz 1983:130; Fredricksmeyer 1965:159 and Tietze 1939:356.

10

See note 3 . 
external factor (a sense impression) initiates symptoms which overwhelm the observer, changing him/her into some helpless sufferer. In fact both poet-personae suffer black-outs eliminating the original sense impression; both are forced to draw the curtain physically on this overwhelming impression of a destructive reality.

The interesting point about both the Catullus and the Sappho poems, however, is that neither poem merely expresses an overwhelming response to the beloved object. Most critics who have problems with the otium section in Catullus c. 51 (and those who ignore verse 17 in Sappho f. 31), want both the Sappho and the Catullus poems to remain relatively uncomplicated "instinctive" love poems. Both are exceptional love poems, but they also function as an expression of the thoughtful creative poetical genius of the two poets which is not simple, instinctive or uncomplicated. Neither poet is therefore content to describe merely a profound physical reaction suggesting in effect that the observer is basically experiencing love as an illness. Both poems also respond to the implied physical threat to the poet-persona.11

The Sappho poem suggests the survival of the individual subtly but most effectively in the grass image (vv. 14b-16a).12 Linked to this image is a cyclic perspective on human affairs. At the point where destruction is imminent (vv. 15-16) revival is implicit. What is suggested in the grass comparison, seems to be expanded in the lost lines beyond v. 17 . Even though the poet-persona at a specific moment is threatened to the point of death, survival too is somehow implicit. Survival triumphs in the form of the creative urge, already making sense of destruction, poetry of the experience of annihilation.

The Catullan solution (if it could be called a solution) to a threatened personal existence differs fundamentally from the Sapphic. The Sappho-persona describes death in terms of an image which reflects total destruction at the present moment but which contains the promise and possibility of life at some future date: grass, which only needs water to come to life again. The Catullan poem relies on a complete shift in perspective to combat the attack on the senses. No longer are the physical reactions of the poet-persona used to portray psychological turmoil. The physical world is cut out and exchanged for the world of thought.

In v. 13 the poet-persona addresses himself. When this happens in a poem, the poet is usually attempting to make a specific situation more understandable and concrete. This is a way of coming to terms with a problem. The problem itself does not change fundamentally, however. The poet's argument is the following: Another man can tolerate, even enjoy Lesbia's company. The poet-persona on the other hand is so severely affected by his reaction to her, that he becomes inarticulate, insensible, imprisoned by his own physical reactions, like someone overwhelmed by illness. 13 Only if he does nothing (i.e., if he does not direct his senses elsewhere, thereby allowing his senses to be responsive to this devastating impression) is he susceptible to the consequences as described in vv. 9-12. The whole point of this stanza has been, however, to describe the inability of the poet to take action himself, to clarify in fact that physically he, like any other seriously ill person, is completely helpless.

11 I am assuming that Sappho f. 31 continues beyond verse 16 and that verses 13-16 form an integral part of Catullus c. 51. See Finamore 1984:11 nn. 1 and 2 for a recent summary of scholarship done on the unity of Catullus c. 51.

12 See Burnett 1983:242 for a good analysis of this image.

13 It is of course essential to realise that these reactions represent the very opposite of the normal state of being for a poet. 
The physical reaction described in vv. 9-12 is immediate, uncomplicated and direct. The experience is overwhelming. The overwhelmed poet-persona, whose physical world has been cut off, remains therefore capable of responding to this physically overwhelming reality only on a mental level or by thought.14 In this case "thought" recommends a seemingly simple solution, namely "activity" to prevent impact from the original sense impression causing the illness or negative reaction. In vv. 13-16 the "activity solution" is quite simple and clear on the surface. The only problem is the basic meaning of otium. Woodman reads different meanings into the use of otium in each different line. He suggests the meaning "lethargy" in otium, Catulle, tibi molestum est (v. 13), "inactivity" in otio exsultas, nimiumque gestis (v. 14) and "disinclination for exertion" in otium et reges prius et beatas perdidit urbes (vv. 15-16).15 Whatever final shade of meaning is attached to otium in general in this stanza or in particular in each verse, it must be clear that active reaction against such a state of general sluggishness is hardly physically possible and not very realistic. Repeating otium at the same place in different cases in three consecutive sentences underlines the fact that the "activity" solution might be simple, but the execution of the solution is close to impossible. How could the poet-persona succeed, where kings and cities have failed? The diagnosis might be available to the poet-persona and might have been available to cities and kings, 16 the cure lies elsewhere, out of reach. According to Stark (1957:332) "There takes place no exhortations to put down this otium or to confine it to a limit which would not lead to self-destruction." Under the circumstances this is exactly what is to be expected.

In the final analysis the Sappho poem and the Catullus poem describe the same situation, the same reality, but the solutions suggested by the two poems differ fundamentally. In the Sappho poem poetry transcends reality in the very image it uses to reflect the total destruction caused by this reality. The poet-persona may resemble dried grass now, 17 in future there will be life and growth again. The poem itself is already proof of new vitality and surging creativity.

The Catullus poem lacks this fundamental optimism. Instead of concentrating on an openended "possible" future like the Sappho poem, this poet-persona looks back at history, with its ample illustration and examples of destruction.18 The Catullan "solution" to the problem of the poem is uncompromisingly realistic. This confrontation with reality will not become bearable with time. Health will not return organically, by itself, given time as in the Sappho poem. Reality cannot be confronted once and for all, but only over and over again. 19

14 Tietze 1939:367: "Catulls Gedicht...zeigt die inneren Möglichkeiten...das Sein zu begreifen und sich ihm gegenüber zu stellen."

15 Woodman (1966:219) further discusses (and rejects) otium meaning leisure and opts for otium meaning inertia, desidia or segnita.

Colaclides (1978:328) identifies two possible causes (one physical and one more abstract) for otium et reges prius et beatas perdidit urbes: physical lethargy ("mollesse") of the people and the idea that prolonged peace and prosperity creates nonchalance which inevitably leads to decline. See also Woodman's meanings for otium as discussed above.

See note 12 .

18 Colaclides (1978:328) describes the historic reference as "une formule traditionelle, constituée d'un élément constant, la référence à la ruine des cités...", but adds that the specific cause, otium, represents "un élément variable, la notion abstraite qui provoque cette ruine." 
The poem itself is the solid and realistic diagnosis of the experience of reality as an illness. An equally solid and realistic cure in the form of Lesbia's positive response to the poem is one possible remedy. On a simple first-level reading of the poem one could say that perfect mental and physical health such as the bliss exemplified by the ille in the first few lines, is only Lesbia's to bestow. 20

A more complex and probably more interesting reading of the poem (especially in the light of the poem's final stanza) is also possible, however. It is quite clear that the poet-persona depicts both the overwhelming physical response to Lesbia's presence as well as the mental realisation of how that response affects him in c. 51. Since neither his initial reaction nor his subsequent insight into his situation can be described as positive (=having some influence on his situation), the poet-persona's very existence as poet is threatened.21 In Catullus' case the entire unsuccessful confrontation with reality is contained in and expressed by the poem. The cause of this failure/illness consists of the overwhelming impact of the sense impressions generated by Lesbia as well as the poet-persona's realisation of his personal inability to support her presence. The symptoms of the illness are helplessness, insensibility (vv. 9-12) [as a natural preserver of the self] and debility (vv. 13-16).22

The cure for the illness needs to address these symptoms very specifically. The failing senses have blocked out the original deadly sense impression. The physical cause of the initial threatening sense reaction is thus automatically removed.

The mental cause of the illness (the poet's own awareness of his response to reality and the insight into his helplessness in this situation) is not left with the despairing cry of otium and nothing else, however. There is after all the physical existence of the poem to counteract the despair of otium. Creative activity has superseded debility. This might not change the poet-persona's physical reaction to the presence of his beloved or his understanding of his total lack of control over the situation. At least the poem is proof that the negotium of the poet's craft has replaced that original fatal otium reaction. Creative control in the form of the poem now confronts reality.

\section{BIBLIOGRAPHY}

Buchner, K. 1976. Die romische Lyrik. Stuttgart: Reclam.

Burnett, A. Pippin. 1983. Three archaic poets: Archilochus, Alcaeus and Sappho. Cambridge: Harvard University Press.

Colaclides, P. 1978. "Note sur la strophe finale du carmen 51 du Catull." Philologus 122:327-328.

Copley, F.O. 1974. "The structure of Catullus c. 51 and the problem of the otiumstrophe." Grazer Beitrage 2:25-37.

Finamore, J.F. 1984. "Catullus 50 and 51: Friendship, love, and otium." CW 78:11-19.

Fredricksmeyer, E.A. 1965. "On the unity of Catullus 51." TAPA 96:153-163.

20 See Fredricksmeyer 1965 for an example of such a reading.

21 Cf. Büchner 1976:32: "Wesentlich is die tragische Spannung, die sich auftut."

22 Wills 1967:195: "It is not love that tortures Catullus, but his debility in the presence of Lesbia." 
Itzkowitz, J.B. 1983. "On the last stanza of Catullus 51." Latomus 42:129-134.

Lefevre, D. 1988. "Otium und $\tau 0 \lambda \mu \hat{\alpha} \nu$ : Catulls Sappho-Gedicht c. 51." RhM 131:324-337.

Stark, R. 1957. "Sapphoreminiszenzen." Hermes 85:325-336.

Schnelle, I. 1933. Untersuchungen zu Catulls dichterischer Form. Leipzig: Dieterich'sche Verlagsbuchhandlung, 17-23. (Philologus Supplementband 25/3).

Snell, B. 1931. "Sappho's ФAINETAI MOI KHNOE." Hermes 66:82-97.

Thom, S. 1990. Alienation, Separation and Loss as Poetic Motivation in Sappho. Unpublished D.Litt. dissertation, University of Stellenbosch.

Tietze, F. 1939. "Catulls 51. Gedicht." RhM 88:346-356.

Wills, G. 1967. "Sappho 31 and Catullus 51." GRBS 8:167-197.

Woodman, A.J. 1966. "Some implications of otium in Catullus." Latomus 25:217-226.

Woodman, A.J. 1978. "Catullus 11 and 51." LCM 3:77-79. 